\title{
ANALISIS PERPUTARAN MODAL KERJA PADA PERUSAHAAN DAERAH AIR MINUM KABUPATEN BANGGAI
}

\author{
Oleh: Fitriani \\ nengfitry6@gmail.com \\ (Program Studi Akuntansi, FEB Universitas Muhammadiyah Luwuk)
}

\begin{abstract}
Abstrak-Modal kerja adalah uang tunai dan aktiva yang mudah diuangkan untuk mendanai kegiatan operasional perusahaan sehari-hari. Perputaran modal kerja menunjukkan hubungan antara banyaknya penjualan bersih dalam satu periode dengan modal kerja yang ada. Tujuan penelitian yaitu untuk mengetahui apakah perputaran modal kerja pada Perusahaan Daerah Air Minum Kabupaten Banggai sudah efisien selama tahun 2014 hingga 2016. Penelitian ini menggunakan pendekatan kuantitatif dan dijabarkan secara deskriptif dengan menggunakan metode wawancara, dokumentasi dan observasi. Hasil perhitungan Rasio Perputaran Modal Kerja Perusahaan Daerah Air Minum Kabupaten Banggai menunjukan bahwa di Tahun 2014 Sampai Tahun 2016 menunjukan hasil kurang efisien dalam penggunaan modal kerja, di karenakan Perusahaan Daerah Air Minum masih dapat membiayai utang jangka pendek. Dari Perhitungan Rasio Periode Terikat Modal Kerja tahun 2014 hingga tahun 2016 menunjukkan hasil yang kurang efisien di karena menghasilkan nilai yang cukup rendah yaitu -179 hari.
\end{abstract}

Kata Kunci: Modal Kerja, Rasio Perputaran Modal, Periode Terikat Modal Kerja.

\begin{abstract}
Working capital is cash and assets that are easily cashable to fund the company's day-to-day operations. Working capital turnover shows the relationship between the number of net sales in one period with the existing working capital. The purpose of this study was to determine whether the working capital turnover at the Regional Water Company of Banggai Regency was efficient during 2014 to 2016. This study used a quantitative approach and described descriptively using interviews, documentation and observation methods. The results of the calculation of the Working Capital Turnover Ratio of the Regional Water Company of Banggai Regency show that in 2014 to 2016 the results were less efficient in the use of working capital, because the Regional Drinking Water Company was still able to finance short-term debt. From the calculation of the Working Capital Bonded Period Ratio in 2014 to 2016 shows the results are less efficient because it produces a fairly low value of -179 days.
\end{abstract}

Keywords: Working Capital, Capital Turnover Ratio, Working Capital Bound Period. 


\section{PENDAHULUAN}

Dalam menghadapi era kompetisi didunia usaha yang ditandai dengan adanya persaingan yang semakin meningkat setiap perusahaan dituntut untuk mempersiapkan diri secara matang. Oleh karena itu, perusahaan harus mempunyai suatu konsep perencanaan yang strategis agar keberadaannya tetap diperhitungkan didunia usaha. Dalam menjalankan kegiatan operasional sehari-hari, setiap perusahaan selalu membutuhkan modal kerja. Modal kerja merupakan salah satu faktor produksi yang paling penting dalam menjalankan kegiatan operasional perusahaan. Penggunaan modal kerja oleh suatu perusahaan dalam kegiatan operasional sehari-hari adalah untuk membelanjai operasinya dalam upaya meningkatkan hasil produksi dengan tujuan untuk memperoleh laba yang maksimal. Maka dari itu setiap perusahaan memerlukan adanya modal kerja yang cukup.

(Kasmir, 2016) menyatakan bahwa modal kerja adalah "Modal yang digunakan untuk melakukan kegiatan operasi perusahaan. Pengertian modal kerja menurut (Djarwanto PS, 2011) adalah kelebihan aktiva lancar terhadap utang jangka pendek. Kelebihan ini disebut modal kerja bersih, Kelebihan ini merupakan jumlah aktiva lancar yang berasal dari utang jangka panjang dan modal sendiri.
Modal kerja juga dapat diartikan sebagai investasi yang ditanamkan dalam aktiva lancar atau aktiva jangka pendek seperti kas, surat-surat berharga, piutang, persediaan dan aktiva lancar lainnya besar kecilnya modal kerja perusahaan tergantung dari jenis perusahaan. (Munawir, 2010) mengemukakan secara umum dikatakan bahwa penggunaan modal kerja biasa digunakan untuk:

1. Pengeluaran untuk gaji, upah, dan biaya operasi perusahaan lainnya, untuk menunjang penjualan.

2. Pengeluaran untuk membeli bahan baku atau barang dagangan yang akan digunakan untuk proses produksi atau untuk dijual kembali.

3. Menutupi kerugian akibat penjualan surat berharga.

4. Pembentukan dana yang merupakan pemisahan aktiva lancar untuk tujuan tertentu dalam jangka panjang, misalnya pembentukan dana pensiun, dana ekspansi, atau dana pelunasan obligasi. Pembentukan dana ini akan mengubah bentuk aktiva dari aktiva lancar menjadi aktiva tetap.

5. Pembelian aktiva tetap (tanah, bangunan, kendaraan, mesin, dan lain-lain).

6. Pembayaran utang jangka panjang (obligasi, hipotek, utang bank jangka panjang). 
7. Pengambilan uang atau barang untuk kepentingan pribadi.

Penentuan jumlah modal kerja sangatlah penting bagi perusahaan, kekurangan modal kerja maka perusahaan akan mengalami masalah likuiditas yaitu tidak bisa membayar kewajiban jangka pendek tepat pada waktunya, akan mengalami kesulitan dalam membeli bahan baku atau bahan pembantu, membayar upah buruh, gaji para karyawan, serta biaya-biaya lainnya yang akan mengakibatkan tidak maksimumnya kegiatan operasional perusahaan.

Indikator Perputaran Modal Kerja (Kasmir, 2016) merupakan salah satu rasio untuk mengukur atau menilai keefektifan modal kerja perusahaan selama periode tertentu. Artinya seberapa banyak modal kerja berputar selama satu periode atau beberapa periode.

Perusahaan Daerah Air Minum Kabupaten Banggai adalah Badan usaha yang bergerak dibidang penjualan air untuk masyarakat. Fenomena yang terjadi adanya persoalan pengelolaan modal kerja menjadi masalah serius dan merupakan aspek yang sering dihadapi perusahaan. Banyak perusahaan yang gulung tikar karena mengalami kondisi tersebut. Karena itu, adanya analisis atas modal kerja sangat penting dilakukan guna mengetahui kondisi modal kerja saat ini kemudian dihubungkan dengan situasi keuangan pada masa yang akan datang.
Untuk melihat kondisi dan perkembangan keuangan suatu perusahaan, biasanya pimpinan perusahaan menyusun laporan keuangan yang menggambarkan kejadian atau segala transaksi yang terjadi diperusahaan yang kemudian digunakan untuk menginterpretasikan data keuangan perusahaan.

(Ikatan Akuntan Indonesia, 2015) dalam Standar Akuntansi Keuangan (SAK) No.1 dikemukakan bahwa Laporan keuangan merupakan bagian dari proses pelaporan keuangan, Laporan Keuangan adalah suatu penyajian terstruktur dari posisi keuangan dan kinerja keuangan suatu entitas. (Wardiyah, 2017) menyatakan laporan keuangan adalah laporan tertulis yang merupakan bentuk pandangan secara wajar mengenai posisi keuangan, kinerja dan arus kas perusahaan yang bermanfaat bagi kalangan pengguna laporan dalam rangka membuat keputusan ekonomi serta menunjukkan pertanggungjawaban manajemen atas penggunaan sumber daya yang ada.

(Muhardi Werner R., 2013) "Tujuan laporan keuangan adalah menyediakan informasi mengenai posisi keuangan, kinerja dan perubahan dalam posisi keuangan sebagai suatu entitas yang bermanfaat dalam pembuatan keputusan. Laporan keuangan perusahaan sangat bermanfaat bagi penganalisis untuk mengetahui 
kondisi dan perkembangan keuangan perusahaan.

Menurut

Penelitian

(Rachmawati \& Andika, 2018) Analisis laporan keuangan (financial statement analysis) adalah aplikasi dari alat dan teknik analisis untuk laporan keuangan bertujuan umum dan data-data yang berkaitan untuk menghasilkan estimasi dan kesimpulan yang bermanfaat dalam analisis bisnis. (Harry, 2015) Menyatakan analisis laporan keuangan merupakan suatu proses untuk membedah laporan keuangan ke dalam unsur unsurnya dan menelaah masing-masing dari unsur tersebut guna memperoleh pengertian dan pemahaman yang baik dan tepat atas laporan keuangan itu sendiri.

Salah satu analisis laporan keuangan adalah analisis laporan sumber dan penggunaan modal kerja dalam suatu perusahaan. Modal kerja merupakan dana yang harus tersedia dalam perusahaan yang dapat digunakan untuk membelanjai kegiatan operasinya sehari-hari, dari laporan tersebut perusahaan juga dapat merencanakan penggunaan modal untuk menghindari hal-hal yang tidak diinginkan perusahaan. Sebab, apabila perusahaan kekurangan modal perusahaan akan sulit berkembang. Kekurangan modal kerja yang terus menerus yang tidak segera diatasi tentu akan menghambat perusahaan dalam mencapai tujuannya.
Penelitian (Dasrizal Masri, 2013) Tentang Analisis Perputaran Modal Kerja Pada Usaha Ekonomi Desa UED-SP TUAH Negeri Rambah Hilir Rokan Hulu (Studi Kasus: UED-SP TUAH Negeri Rambah Hilir Rokan) Hasil penelitian menunjukan perputaran modal kerja tahun 2010 sebanyak 0,24 kali, perputaran modal kerja pada tahun 2011 sebanyak 0,24 kali dan pada tahun 2012 periodeperputaran modal kerja sebanyak 0,29 kali. Jadi periode perputaran modal kerja sangat lamban mengakibatkan perputaran modal kerja tidak efektif.

Penelitian (Nur Azlina, 2016) tentang Analisis Perputaran Modal Kerja Pada PTP Nusantara II Kebun Arso Kabupaten Keerom menunjukan perputaran kas berdasarkan data perusahaan PTP Nusantara II Kebun Arso menunjukkan manajemen kas pada perusahaan baik dalam memanfaatkan kas yang dimiliki. Perputaran piutang Perusahaan PTP Nusantara II Kebun Arso sangat baik dalam pengembalian piutang menjadi kas, namun lebih lambat pada tahun 2016. Sementara perputaran persediaan barang yang akan dijual dan dikembalikan menjadi kas pada tahun 2014-2016. Perputaran modal kerja PTP Nusantara II Kebun Arso Kabupaten Keerom rendah pada tahun 2014-2016, perputaran modal kerja hanya satu yang 
menunjukkan bahwa penjualan lebih besar dibanding modal kerja.

Penelitian yang dilakukan oleh (Nur Azlina, 2016) tentang Pengaruh Tingkat Perputaran Modal Kerja, Struktur Modal Dan Skala Perusahaan Terhadap Profitabilitas. Hasil Penelitiannya menunjukan tingkat perputaran modal kerja, struktur modal dan skala perusahaan secara simultan berpengaruh signifikan terhadap profitabilitas pada perusahaan Property and Real Estate di BEI sedangkan secara Parsial hanya Tingkat Perputaran Modal kerja dan Struktur Modal yang berpengaruh terhadap profitabilitas sedangkan Skala Perusahaan tidak berpengaruh.

Dengan demikian, peneliti tertarik untuk melakukan penelitian pada Perusahaan Daerah Air Minum Kabupaten Banggai. Hal tersebut dilakukan dengan pertimbangan bahwa penggunaan modal kerja merupakan masalah yang penting, karena dengan penggunaan modal kerja yang baik sebuah perusahaan akan dapat memenuhi kewajibankewajiban tersebut sehingga dalam operasinya selalu dapat memberikan keuntungan maksimal agar perusahaan dapat beroperasi secara ekonomis dan efisien.

\section{METODE PENELITIAN}

Jenis Penelitian yang digunakan dalam penelitian ini adalah Deskriptif Kuantitatif. (Arikunto S, 2016) Penelitian deskriptif adalah penelitian yang dimaksudkan untuk menyelidiki keadaan, kondisi atau hal lain-lain yang sudah disebutkan, yang hasilnya dipaparkan dalam bentuk laporan penelitian. Penelitian dilakukan dari bulan Juni sampai Agustus 2017. Penelitian bertempat di Perusahaan Daerah Air Minum Kabupaten Banggai. Subjek dalam penelitian ini adalah kantor Perusahaaan Daerah Air Minum (PDAM) Kab. Banggai, Sedangkan yang menjadi objek dalam penelitian ini adalah Laporan Keuangan PDAM Kab. Banggai dari Tahun 2014-2016. Tehnik pengumpulan data dalam penelitian ini menggunakan metode Wawancara, Observasi dan Dokumentasi.

HASIL DAN PEMBAHASAN

Tabel 1. Aktiva Perusahaan PDAM Kab. Banggai Tahun 2013-2016

\begin{tabular}{|l|l|r|r|r|}
\hline No & Tahun & $\begin{array}{c}\text { Aktiva Lancar } \\
(\mathbf{R p})\end{array}$ & $\begin{array}{c}\text { Aktiva Tetap } \\
(\mathbf{R p})\end{array}$ & $\begin{array}{c}\text { Total Aktiva } \\
(\mathbf{R p})\end{array}$ \\
\hline 1 & 2013 & $2.084 .382 .195,00$ & $1.381 .246 .783,00$ & $3.465 .628 .978,00$ \\
\hline 2 & 2014 & $2.416 .115 .745,00$ & $1.209 .229 .656,00$ & $3.625 .345 .401,00$ \\
\hline 3 & 2015 & $2.951 .921 .124,00$ & $1.028 .228 .800,00$ & $3.980 .149 .924,00$ \\
\hline 4 & 2016 & $3.123 .966 .050,00$ & $802.949 .688,00$ & $3.926 .915 .738,00$ \\
\hline
\end{tabular}

Sumber: Laporan Keuangan PDAM Kab. Banggai, 2017. 
Dari Tabel di atas terlihat bahwa perkembangan aktiva lancar maupun aktiva tetap berubah-ubah. Pada tahun 2013 total aktiva lancar sebesar Rp. 3.465.628.978,00. Tahun 2014 mengalami kenaikan sebesar Rp. 3.625.345.401,00. Tahun 2015 mengalami kenaikan menjadi $\mathrm{Rp}$. 3.980.149.924,00, dan tahun 2016 mengalami penurunan dari tahun 2015 menjadi Rp. 3.926.915.738,00.

Untuk aktiva tetap pada tahun 2013 adalah sebesar Rp.1.381.246.783,00. Tahun 2014 mengalami penurunan dibandingkan tahun 2013 menjadi Rp. 1.209.229.656,00. Tahun 2015 mengalami penurunan dibandingkan tahun sebelumnya 2014 yaitu menjadi Rp.1.028.228.800,00 dan tahun 2016 terjadi penurunan kembali dibandingkan tahun 2015, menjadi Rp. 802.949.688,00.

Untuk aktiva lancar mengalami perubahan seiring terjadi perubahan pada aktiva lancar maupun aktiva tetap. Pada tahun 2013 aktiva lancar adalah sebesar Rp.2.084.382.195,00. Tahun 2014 mengalami kenaikan menjadi Rp.2.416.115.745,00 dibandingkan tahun 2013. Tahun 2015 mengalami kenaikan aktiva lancar dibandingkan tahun sebelumnya menjadi Rp. 2.951.921.124,00,. Tahun 2016 kembali mengalami kanaikan dibandingkan tahun 2015 yaitu menjadi Rp.3.123.966.050,00.

Jika dilihat dari tabel diatas sebagian besar aktiva lancer, aktiva tetap dan total aktiva selama kurun waktu 2013 hingga tahun 2016 mengalami penurunan.

Tabel 2. Piutang Perusahaan PDAM Kab. Banggai 2013-2016

\begin{tabular}{|c|c|c|c|c|}
\hline No & Tahun & $\begin{array}{c}\text { Piutang Usaha } \\
(\mathbf{R p})\end{array}$ & $\begin{array}{c}\text { Piutang Lain - } \\
\text { Lain } \\
(\mathbf{R p})\end{array}$ & $\begin{array}{c}\text { Total Piutang } \\
(\mathbf{R p})\end{array}$ \\
\hline 1 & 2013 & $1.596 .837 .876,00$ & $233.794 .873,00$ & $1.830 .632 .749,00$ \\
\hline 2 & 2014 & $2.076 .703 .652,00$ & $233.389 .873,00$ & $2.310 .093 .525,00$ \\
\hline 3 & 2015 & $2.566 .728 .652,00$ & $233.389 .873,00$ & $2.800 .118 .525,00$ \\
\hline 4 & 2016 & $2.668 .605 .959,00$ & $233.389 .873,00$ & $2.901 .995 .832,00$ \\
\hline
\end{tabular}

Sumber: Laporan Keuangan PDAM Kab. Banggai, 2017

Dari tabel diatas terlihat bahwa piutang usaha tahun 2013 sebesar Rp.1.596.837.876,00. Tahun 2014 mengalami kenaikan sebesar Rp.2.076.703.652,00. Tahun 2015 piutang usaha mengalami kenaikan sebesar Rp.2.566.728.652,00 dan untuk tahun 2016 mengalami kenaikan kembali menjadi Rp.2.668.605.959,00.

Piutang lain- lain pada tahun 2013 adalah sebesar Rp.233.794.873,00. Tahun 2014 sampai tahun 2016 bernilai sama sebesar Rp. 233.389.873,00. Terlihat bahwa total piutang tahun 2013 
adalah sebesar Rp.1.830.632.749,00. Tahun 2014 mengalami kenaikan piutang sebesar Rp.2.310.093.525,00. Tahun 2015 mengalami kenaikan menjadi
Rp.2.800.118.525,00, dan Tahun 2016 mengalami kenaikan yaitu sebesar

Rp.2.901.995.832,00 dibandingkan tahun 2015 .

Tabel 3. Pendapatan PDAM Kab. Banggai Tahun 2013-2016

\begin{tabular}{|l|c|c|c|c|}
\hline No & Tahun & $\begin{array}{c}\text { Pendapatan Air } \\
\text { (Rp) }\end{array}$ & $\begin{array}{c}\text { Pendapatan Non } \\
\text { Air } \\
(\mathbf{R p})\end{array}$ & $\begin{array}{c}\text { Total } \\
\text { Pendapatan } \\
(\mathbf{R p})\end{array}$ \\
\hline 1 & 2013 & $6.919 .001 .700,00$ & $12.298 .150,00$ & $7.741 .671 .713,00$ \\
\hline 2 & 2014 & $6.858 .743 .350,00$ & $18.892 .950,00$ & $6.877 .636 .300,00$ \\
\hline 3 & 2015 & $6.984 .541 .000,00$ & $12.653 .400,00$ & $6.997 .194 .400,00$ \\
\hline 4 & 2016 & $6.869 .127 .400,00$ & $14.689 .550,00$ & $6.883 .816 .950,00$ \\
\hline
\end{tabular}

Sumber: Laporan Keuangan PDAM Kab. Banggai, 2017

Dari tabel diatas terlihat bahwa pendapatan air tahun 2013 sebesar Rp. 6.919.001.700,00. Tahun 2014 mengalami penurunan sebesar Rp.6.858.743.350,00. Tahun 2015 mengalami kenaikan sebesar Rp.6.984.541.000,00, dan untuk Tahun 2016 mengalami penurunan kembali menjadi Rp.6.869.127.400,00.

Pendapatan non air pada tahun 2013 adalah sebesar Rp.12.298.150,00. Tahun 2014 mengalami kenaikan sebesar Rp.18.892.950,00. Tahun 2015 mengalami penurunan sebesar Rp.12.653.400,00, dan di Tahun 2016 menalami kenaikan sebesar Rp. 14.689.550,00.

Dari tabel diatas terlihat bahwa total pendapatan tahun 2013 adalah sebesar Rp. 7.741.671.713,00. Tahun 2014 mengalami penurunan pendapatan yaitu sebesar Rp.6.877.636.300,00, untuk tahun
2015 mengalami kenaikan kembali menjadi Rp.6.997.194.400,00, dan tahun 2016 mengalami penurunan yang cukup kecil yaitu sebesar Rp.6.883.816.950,00 dibandingkan tahun 2015.

Untuk menghitung efisiensi modal kerja digunakan beberapa rasio sebagai berikut:

Tingkat Perputaran Modal Kerja:

$$
\frac{\text { Penjualan Bersih }}{\text { Aktiva Lancar-Utang Lancar }}
$$

Periode Terikatnya:

$$
360 \text { Hari }
$$

$\overline{\text { Tingkat Perputaran Modal Kerja }} \times 1$ Hari

Tahun 2014 $=\frac{6.877 .636 .300,00}{-2.246 .431 .592}=-3,06$

Periode Terikatnya:

$$
\frac{360}{-3,06} \times 1 \text { Hari }=-118 \text { Hari }
$$

Tahun $2015=\frac{6.997 \cdot 194.400,00}{-2.246 .431 .592}=-3,14$

Periode Terikatnya: 


$$
\frac{360}{-3,14} \times 1 \text { Hari }=-115 \text { Hari }
$$

$$
\frac{360}{6,71} \times 1 \text { Hari }=54 \text { Hari }
$$

Tahun $2016=\frac{6 \cdot 883 \cdot 816 \cdot 950,00}{1 \cdot 026 \cdot 490 \cdot 160,00}=6,71$

Periode Terikatnya:

\begin{tabular}{|c|c|c|c|c|c|}
\hline No & Tahun & $\begin{array}{l}\text { Penjualan } \\
\text { (Rp) }\end{array}$ & $\begin{array}{l}\text { Aktiva Lancar- } \\
\text { Utang Lancar } \\
\text { (Rp) }\end{array}$ & PMK & Ket \\
\hline 1 & 2014 & $6.877 .636 .300,00$ & $-2.246 .431 .592,00$ & $-3,06$ & Kurang Efisien \\
\hline 2 & 2015 & $6.997 .194 .400,00$ & $-2.246 .431 .592,00$ & $-3,14$ & Kurang Efisien \\
\hline 3 & 2016 & $6.883 .816 .950,00$ & $1.026 .490 .160,00$ & 6,71 & Efisien \\
\hline \multicolumn{4}{|c|}{ Rata - Rata } & 0,51 & \\
\hline
\end{tabular}

Tabel 4. Rasio Perputaran Modal Kerja PDAM Kab. Banggai 2014-2016

Sumber: Laporan Keuangan PDAM Kab. Banggai, 2017

Tabel 5. Rasio Periode Terikat Modal Kerja PDAM Kab. Banggai Tahun 2014-2016

\begin{tabular}{|c|c|c|c|c|}
\hline No & Tahun & 360 Hari & $\begin{array}{c}\text { Perputaran Modal } \\
\text { Kerja }\end{array}$ & $\begin{array}{c}\text { Periode } \\
\text { Terikat MK }\end{array}$ \\
\hline 1 & 2014 & 360 & $-3,06$ & -118 Hari \\
\hline 2 & 2015 & 360 & $-3,14$ & -115 Hari \\
\hline 3 & 2016 & 360 & 6,71 & 54 Hari \\
\hline \multicolumn{3}{|c|}{ Rata - Rata } & -179 Hari \\
\hline
\end{tabular}

Sumber: Laporan Keuangan PDAM Kab. Banggai, 2017

PEMBAHASAN

Dari hasil perhitungan rasio lancar atau (Current Ratio) pada tabel 4 Rasio Perputaran Modal Kerja Perusahaan Daerah Air Minum Kabupaten Banggai Tahun 2014 adalah sebesar -3,06 yang artinya bahwa setiap Rp. -3,06 penjualan dihasilkan oleh modal kerja sebesar Rp. 1, nilai dalam kategori tidak efisien, karena aktiva Perusahaan Daerah Air Minum masih dapat membiayai utang jangka pendek bila dikaitkan dengan indikator pengukurannya maka tahun 2014 dikatakan kurang efisien dalam penggunaan modal kerjanya.

Tahun 2015 nilai dari rasio lancar ini adalah $-3,14$ yang artinya setiap Rp.-3,14 penjualan dibiayai oleh modal kerja sebesar Rp. 1, nilai dari rasio ini masih dirasakan tidak efisien karena saat perusahaan membiayai penjualan perusahaan belum mampu untuk menggunakan modal kerjanya. Untuk tahun 2016 
nilai dari rasio lancar adalah sebesar 6,71 yang artinya setiap Rp.6,71 penjualan mampu dihasilkan oleh modal kerjanya sebesar Rp. 1, dimana hasil rasio ini menunjukkan hasil yang efisien, karena perusahaan mampu menghasilkan penjualan dengan modal kerjanya.

Dari penjelasan diatas mengindikasikan bahwa perputaran modal kerja perusahaan selama kurun waktu 2014 hingga tahun 2016 jika dirata-ratakan hanya sebesar 0,51 , nilai ini sangat kurang dikarena kategorinya kurang efisien, karena apabila perusahaan membiayai penjualannya dengan seluruh aktiva lancarnya dikurangi kewajiban lancar, perusahaan kekurangan hampir $99 \%$ dari sisa aktiva lancar yang dimiliki, sehingga perusahaan harus lebih maksimal dalam memanfaatkan seluruh aktiva lancarnya.

Dari hasil perhitungan Periode Terikat Modal Kerja pada tabel 5 diatas terlihat bahwa pada tahun 2014 periode terikat modal kerja sebesar-118 yang artinya perusahaan dalam satu periode tidak mampu menghasilkan keuntungan bahkan harus mempunyai waktu tambahan waktu 118 hari kedepan untuk menghasilkan penjualan yang maksimal.

Tahun 2015 cenderung nilai rasio ini turun menjadi 115 hari atau lebih kecil jika dibandingkan dengan tahun 2014, yang artinya tahun 2015 ini perusahaan tidak mampu mengembalikan modal kerja dan harus menunggu selama 115 hari kedepan sehingga dalam satu periode perusahaan tidak mampu untuk menghasilkan penjualan. Tahun 2016 mengalami peningkatan menjadi 57 hari atau pada tahun 2016 ini perusahaan mampu mengembalikan modal kerjanya hanya dengan 57 hari dalam satu periode, ini dikategorikan cukup efisien karena jika di hitung maka perusahaan dalam satu tahun dapat berputar sebanyak 6 kali perputaran modal kerjanya. Dari penjelasan tersebut diatas mengindikasikan tahun 2014 sampai 2016 perusahaan masih dalam kondisi yang kurang efisien dari sisi priode terikat modal kerja.

Perusahaan Daerah Air Minum Kabupaten Banggai dalam melaksanakan kegiatannya, berusaha meningkatkan usahanya agar tumbuh dan berkembang dengan baik dalam hal meningkatkan kualitas air minum maupun meningkatkan pelayanannya kepada masyarakat. Oleh karena itu modal kerja yang cukup dapat membiayai semua kegiatan operasional perusahaan. Tetapi yang terjadi pada perusahaan daerah air minum Kabupaten Banggai, tidak mampu menghasilkan modal kerja yang mampu membiayai kegiatan operasionalnya, karena jumlah penjualan air yang dihasilkan tidak mampu menutupi nilai modal kerja bersih selama beberapa periode yaitu 2014 sampai 2016, karena rata-rata perusahaan harus mengumpulkan 
modal kerja hampir 2 tahun lamanya untuk satu periode kegiatan operasionalnya.

\section{KESIMPULAN}

Hasil perhitungan Rasio Perputaran Modal Kerja Perusahaan Daerah Air Minum Kabupaten Banggai Kurun Waktu 2014 Sampai 2016 kurang efisien dalam penggunaan modal kerja, sedangkan untuk periode terikat modal kerja tahun 2014 hingga tahun 2016 menunjukkan hasil yang kurang efisien.

Dari simpulan diatas, maka saran dari penulis adalah:

1. Sebaiknya Direktur Perusahaan Daerah Air Minum Kabupaten Banggai lebih efisien dalam penggunaan modal kerja dan mengelolanya dengan sebaik mungkin guna pencapaian keuntungan perusahaan, dengan mengurangi biaya - biaya yang tidak penting dalam kegiatan operasional perusahaan.

2. Dalam penggunaan modal kerja sebaiknya pihak perusahaan memaksimalkan aktiva sebagai sumber modal kerja, dengan cara menggunakan kas sebijak mungkin, dan memaksimalkan penagihan piutang, dan aktiva lancar lainnya guna peningkatan pendapatan yang lebih maksimal lagi.

3. Sebaiknya pihak Perusahaan dalam penggunaan modal kerja seharusnya dapat diefisienkan sehingga perusahaan dapat memperoleh keuntungan yang maksimal. Untuk itu perusahaan sebaiknya perlu melakukan atau membuat laporan sumber dan penggunaan modal, guna mengetahui bagaimana modal kerja itu didapatkan dan digunakan untuk kegiatan operasional perusahaan.

\section{DAFTAR PUSTAKA}

Arikunto S. (2016). Prosedur Penelitian Suatu Pendekatan Praktik. Rineka Cipta.

Dasrizal Masri. (2013). Analisis Perputaran Modal Kerja Pda Usaha Ekonomi Desa UED-SP TUAH Negeri Rambah Hilir Rokan Hulu (Studi Kasus: UED-SP TUAH Negeri Rambah Hilir Rokan_. Jurnal Mahasiswa Prodi Manajemen UPP, 283.

Djarwanto PS. (2011). Pokok-pokok Analisa Laporan Keuangan (Edisi Ke L). BPFE.

Harry. (2015). Analisis Laporan Keuangan (Edisi 1). Center For Academic Publishing Services.

Ikatan Akuntan Indonesia. (2015). Standar Akuntansi Keuangan ETAP. Ikatan Akuntan Indonesia.

Kasmir. (2016). Analisis Laporan Keuangan. PT. RajaGrafindo Persada.

Muhardi Werner R. (2013). Analisis Laporan Keuangan Proyeksi dan Valuasi Saham. Salemba Empat.

Munawir. (2010). Analisa laporan keuangan (edisi 4). Liberty.

Nur Azlina. (2016). Analisis 
Perputaran Modal Kerja Pada PTP Nusantara II Kebun Arso Kabupaten Keerom. Jurnal Ilmu Pengetahuan Dan Teknologi, 7(1979.2271.771979.227149), 22-33.

Prastowo, D. (2015). Analisis Laporan Keuangan Konsep Dan Aplikasi (Ke Tiga). UPP STIM YKPN.

Rachmawati, D. W., \& Andika, S. (2018). Kinerja Keuangan Perbankan Di Indonesia Tahun 2015 Dilihat Dari Sudut Rasio Likuiditas Dan Rasio Solvabilitas Sebagai Sumber Belajar Pada Mata Kuliah Analisa Laporan Keuangan. Jurnal Neraca: Jurnal Pendidikan Dan Ilmu Ekonomi Akuntansi, 1(2), 16-31. https://doi.org/10.31851/neraca .v1i2.2208

Wardiyah, M. L. (2017). Analisis Laporan Keuangan. CV. Pustaka Setia.

Zahruddin Hodsay, F. N. (2017). Analisis Rasio Laporan Keuangan Koperasi Pelajar Di SMK Negeri 1 Palembang. JURNAL NERACA (Jurnal Pendidikan Dan Ilmu Ekonomi), 1(1), 99-108. 